\title{
COMPLEXITY OF PEDIATRIC CHRONIC DISEASE: CROSS-SECTIONAL STUDY WITH 16,237 PATIENTS FOLLOWED BY MULTIPLE MEDICAL SPECIALTIES
} Complexidade da doença crônica pediátrica: estudo tranversal com 16.237 pacientes seguidos por múltiplas especialidades médicas

\author{
Caroline Gouveia Buff Passone (D), Sandra Josefina Grisia (D), Sylvia Costa Farhata (D), \\ Thais Della Manna ${ }^{a}$ (D) Antonio Carlos Pastorino ${ }^{a}$ (D), Renata Antunes Alveno ${ }^{a}$ (D), \\ Caroline Vasconcelos Sá Miranda ${ }^{a}$ id, Aurora Rosaria Waetge ${ }^{a}$ id, \\ Mariana Nutti Cordon ${ }^{a}$ (D), Vicente Odone-Filho ${ }^{a}$ (D), Uenis Tannuria (D), \\ Werther Brunow Carvalho ${ }^{a}$ (D) Magda Carneiro-Sampaio ${ }^{a}$ (D) Clovis Artur Silva ${ }^{a, *}$
}

\section{ABSTRACT}

Objective: To assess demographic data and characteristics of children and adolescents with pediatric chronic diseases (PCD), according to the number of specialties/patient.

Methods: We performed a cross-sectional study with 16,237 PCD patients at outpatient clinics in one year. Data were analyzed by an electronic data system, according to the number of physician appointments for PCD. This study assessed: demographic data, follow-up characteristics, types of medical specialty, diagnosis (International Statistical Classification of Diseases and Related Health Problems - ICD-10), number of day hospital clinic visits, and acute complications.

Results: Patients followed by $\geq 3$ specialties simultaneously showed a significantly higher duration of follow-up compared to those followed by $\leq 2$ specialties [2.1 (0.4-16.4) vs. 1.4 (0.116.2 ) years; $p<0.001]$ and a higher number of appointments in all specialties. The most prevalent medical areas in patients followed by $\geq 3$ specialties were: Psychiatry (Odds Ratio $\mathrm{OR}=8.0$; confidence interval of $95 \%-95 \% \mathrm{Cl} 6-10.7$; $p<0.001$ ), Palliative/Pain Care (OR=7.4; 95\%Cl 5.7-9.7; $p<0.001)$, Infectious Disease (OR=7.0; $95 \% \mathrm{Cl} 6.4-7.8 ; \mathrm{p}<0.001)$ and Nutrology (OR=6.9; 95\% Cl 5.6-8.4; $p<0.001)$. Logistic regressions demonstrated that PCD patients followed by $\geq 3$ specialties were associated with high risk for: number of appointments/ patient (OR=9.2; 95\%Cl 8.0-10.5; $p<0.001)$, day hospital clinic

\section{RESUMO}

Objetivo: Avaliar dados demográficos e características de crianças e adolescentes com doenças crônicas pediátricas, de acordo com o número de especialidades/paciente.

Métodos: Realizou-se um estudo transversal com 16.237 pacientes com doenças crônicas pediátricas durante um ano. A análise foi feita em um sistema eletrônico, de acordo com número de consultas médicas para doenças crônicas pediátricas. Este estudo avaliou dados demográficos, características do seguimento, tipos de especialidades médicas, diagnóstico (10ª Revisão da Classificação Estatística Internacional de Doenças e Problemas Relacionados com a Saúde - CID-10), número de visitas e complicações agudas. Resultados: Os pacientesacompanhados por trêsou mais especialidades simultaneamente tiveram seguimento de maior duração comparados com aqueles seguidos por $\leq 2$ especialidades $[2,1(0,4-16,4)$ vs. 1,4 $(0,1-16,2)$ anos; $p<0,001]$, bem como maior número de consultas em todas as especialidades. As áreas médicas mais comuns em pacientes acompanhados por $\geq 3$ especialidades foram: psiquiatria (Odds Ratio —OR=8,0; intervalo de confiança de 95\% — IC95\% 6-10,7; $p<0,001)$; dor/cuidados paliativos (OR=7,4; IC95\% 5,7-9,7; $p<0,001)$; doenças infecciosas (OR=7,0; IC95\% 6,4-7,8; $p<0,001)$; nutrologia (OR=6,9; IC95\% 5,6-8,4; $p<0,001)$. As regressões logísticas mostraram que os pacientes com doenças crônicas pediátricas seguidos por $\geq 3$ especialidades tinham alto risco para: maior número de consultas/ paciente (OR=9,2; IC95\% 8,0-10,5; $p<0,001)$; atendimentos em

*Corresponding author. E-mail: clovis.silva@hc.fm.usp.br (C.A. Silva).

aniversidade de São Paulo, São Paulo, SP, Brazil.

Received on April 09, 2018; approved on August 30, 2018; available online on November 08, 2019. 
visits (OR=4.8; 95\%Cl 3.8-5.9; $\mathrm{p}<0.001)$, emergency department visits (OR=3.2; $95 \% \mathrm{Cl} 2.9-3.5 ; p<0.001)$, hospitalizations $(\mathrm{OR}=3.0 ; 95 \% \mathrm{Cl} 2.7-3.3 ; \mathrm{p}<0.001)$, intensive care admissions $(\mathrm{OR}=2.5 ; 95 \% \mathrm{Cl} 2.1-3.0 ; \mathrm{p}<0.001)$, and deaths $(\mathrm{OR}=2.8 ; 95 \% \mathrm{Cl}$ 1.9-4.0; $p<0.001)$. The diagnosis of asthma, obesity, chronic pain, and transplant was significantly higher in patients followed by $\geq 3$ specialties.

Conclusions: The present study showed that PCD patients who required simultaneous care from multiple medical specialties had complex and severe diseases, with specific diagnoses.

Keywords: Chronic disease; Child; Adolescent; Emergency; Intensive care unit; Hospitalization. hospital-dia (OR=4,8; 95\%IC3,8-5,9; $p<0,001)$; atendimentos em pronto-socorro (OR=3,2; IC95\% 2,9-3,5; $p<0,001)$; hospitalizações (OR=3,0; IC95\%2,7-3,3; $p<0,001)$; internação em terapia intensiva (OR=2,5; IC95\% 2,1-3,0; $p<0,001)$; óbitos (OR=2,8; IC95\%1,9-4,0; $\mathrm{p}<0,001)$. Os diagnósticos de asma, obesidade, dor crônica, transplante e infecção do trato urinário foram mais frequentes nos pacientes seguidos por três ou mais especialidades.

Conclusões: O presente estudo mostrou que pacientes com doenças crônicas pediátricas que necessitaram de múltiplas especialidades médicas simultaneamente apresentavam doenças complexas e graves, com diagnósticos específicos.

Palavras-chave: Doença crônica; Criança; Adolescente; Emergência; Unidade de cuidados intensivos; Hospitalização.

other hospitalizations were excluded. The Ethics Committee of our University Hospital approved this study.

PCDs were classified according to the duration of the disease (over three months), and the diagnosis was established by the physician's scientific knowledge, valid methods or tools based on professional standards, and/or diagnostic classification criteria. ${ }^{1,6}$ The 10th Revision of the International Statistical Classification of Diseases and Related Health Problems (ICD-10) was also systematically evaluated to characterize the main PCD diagnoses. ${ }^{6,21}$ We assessed the following 23 pediatric specialties, according to the electronic data system: Allergy \& Immunology, Cardiology, Endocrinology, Gastroenterology, Genetics, Hematology, Hematopoietic Cell Transplantation, Hepatology, Infectious Diseases, Nephrology/Renal Transplantation, Neurology, Nutrology, Oncology, Orthopedics, Palliative and Pain Care, Pediatric Surgery/Liver Transplantation, Pulmonology, Psychiatry, Rheumatology, and others (Adolescent Care, Preterm Care, and Pediatric Teaching Clinic).

We conducted data analyses using the electronic data system of institution, according to the number of physician appointments for PCDs. This study assessed: demographic data (current age, gender, and local of residence); characteristics of follow-up (duration, number of physician's appointments/patient, and number of specialties/patient), types of pediatric specialty, number of day hospital clinic visits, and acute complications (number of emergency department visits, hospitalizations, intensive care unit admissions, and deaths). The etiology of each diagnosis was established based on ICD-10.

We divided the PCD patients into two groups, according to the number of pediatric specialties/patient: $\geq 3$ specialties and $\leq 2$ specialties.

The sample size provided a power of $80 \%$ to find differences of less than $2 \%$ in the two groups: $\geq 3$ specialties and $\leq 2$ 
specialties (GraphPad StatMate 1.01, GraphPad Software, Inc., CA, USA). The IBM-SPSS-22 software performed the statistical analyses. We presented the results as median (range) or mean \pm standard deviation (SD) for continuous variables and number (\%) for categorical variables. Mann-Whitney test or Student's t-test compared the continuous variables between the two study groups ( $\geq 3$ specialties and $\leq 2$ specialties). For categorical variables, the differences were evaluated by Fisher's exact test. The multivariate analysis was carried out using backward stepwise logistic regression. In the regression model, the dependent variable was the presence of $\geq 3$ specialties, and the independent variables were those with less than $20 \%$ significance level in the univariate analysis. For all statistical tests, $\mathrm{p}<0.05$ was considered significant.

\section{RESULTS}

From January to December 2015, 16,237 children and adolescents with PCDs were followed by 23 pediatric specialties in our Children's Hospital.

Table 1 Demographic data and characteristics of 16,237 children and adolescents with pediatric chronic diseases followed in a University Hospital, according to the number of specialties/patient.

\begin{tabular}{|c|c|c|c|}
\hline & $\geq 3$ & $\leq 2$ & \multirow{2}{*}{ p-value } \\
\hline & $(n=2,016)$ & $(n=14,221)$ & \\
\hline \multicolumn{4}{|l|}{ Demographic data } \\
\hline Children (<10 years of age) [n (\%)] & $1,095(54)$ & $7670(54)$ & 0.76 \\
\hline Current age in years & $9.0(0.2-19.9)$ & $9.1(0-19.9)$ & 0.67 \\
\hline Females [n (\%)] & $920(46)$ & $6,643(47)$ & 0.37 \\
\hline Residence in São Paulo [n (\%)] & $1,860(92)$ & $13,275(93)$ & 0.07 \\
\hline Duration of follow-up in years & $2.1(0.4-16.4)$ & $1.4(0.1-16.2)$ & $<0.001$ \\
\hline
\end{tabular}

Physician appointment at outpatient clinics

Number of appointments per patient

\begin{tabular}{|c|c|c|c|}
\hline $1-3[n(\%)]$ & $90(4.5)$ & $9,700(68)$ & $<0.001$ \\
\hline $4-12[n(\%)]$ & $1,439(71)$ & $4,043(28)$ & $<0.001$ \\
\hline$\geq 13[n(\%)]$ & $487(24)$ & $478(3)$ & $<0.001$ \\
\hline \multicolumn{4}{|l|}{ Type of medical specialty } \\
\hline Cardiology & $303(15)$ & $460(3)$ & 0.008 \\
\hline Endocrinology & $670(33)$ & $2,108(15)$ & $<0.001$ \\
\hline Gastroenterology & $444(22)$ & $641(5)$ & $<0.001$ \\
\hline Genetics & $475(24)$ & $976(7)$ & $<0.001$ \\
\hline Hematology & $205(10)$ & $541(4)$ & $<0.001$ \\
\hline Hematopoietic cell transplantation & $57(3)$ & $79(1)$ & $<0.001$ \\
\hline Hepatology & $519(26)$ & $1017(7)$ & $<0.001$ \\
\hline Immunology and allergy & $322(16)$ & $941(7)$ & $<0.001$ \\
\hline Infectious disease & $947(47)$ & $1,590(11)$ & $<0.001$ \\
\hline Nephrology and renal transplantation & $556(28)$ & $1,116(8)$ & $<0.001$ \\
\hline Neurology & $328(16)$ & $735(5)$ & $<0.001$ \\
\hline Nutrology & $192(9)$ & $215(2)$ & $<0.001$ \\
\hline Oncology & 251(13) & $1,759(12)$ & 0.92 \\
\hline Orthopedics & $8(0.4)$ & $10(0.1)$ & 0.001 \\
\hline Palliative and pain care & $115(6)$ & $115(1)$ & $<0.001$ \\
\hline Pediatric surgery and liver transplantation & $564(28)$ & $2,018(14)$ & $<0.001$ \\
\hline Pulmonology & $504(25)$ & $994(7)$ & $<0.001$ \\
\hline Psychiatry & $98(5)$ & $90(1)$ & $<0.001$ \\
\hline Rheumatology & $191(10)$ & $590(4)$ & $<0.001$ \\
\hline Others & $570(28)$ & $1,708(12)$ & $<0.001$ \\
\hline
\end{tabular}

Results are presented in $n(\%)$, median (range), or meantstandard deviation. 
Table 1 includes demographic data and characteristics of these children and adolescents with PCDs followed in a University Hospital, according to the number of specialties/ patient. Patients followed by $\geq 3$ specialties showed a significantly higher duration of follow-up compared to those followed by $\leq 2$ specialties [ 2.1 (confidence interval of $95 \%-$ 95\%CI $0.4-16.4)$ vs. $1.4(95 \%$ CI $0.1-16.2)$ years; $\mathrm{p}<0.001]$, similar to the number of appointments in all specialties $(\geq 3$ specialties $=24 \%$ vs. $\leq 2$ specialties $=3 \% ; \mathrm{p}<0.001)$. Frequencies of pediatric specialties, such as Infectious Disease (47 vs. 11\%; $\mathrm{p}<0.001$ ), Endocrinology (33 vs. $15 \%$; $<<0.001$ ), Nephrology/ Renal Transplantation (28 vs. $8 \%$; $\mathrm{p}<0.001$ ), and Pediatric Surgery/Liver Transplantation ( 28 vs. $14 \%$; $\mathrm{p}<0.001$ ), were significantly higher in the former group. We found no differences in patients followed by Oncology (Table 1). Patients followed by $\geq 3$ specialties had significantly higher frequencies of day hospital clinic visits ( 7 vs. $2 \%$; $p<0.001$ ), emergency department visits ( 45 vs. $21 \%$; $\mathrm{p}<0.001$ ), hospitalizations ( 35 vs. $15 \%$; $\mathrm{p}<0.001$ ), intensive care admissions ( 9 vs. $4 \% ; \mathrm{p}<0.001$ ), and deaths ( 2 vs. $1 \%$; $\mathrm{p}<0.001$ ) (Table 2 ).

Table 3 illustrates the logistic regression analysis between the dependent variable ( $\geq 3$ specialties) and the number of appointments, types of specialty, hospitalizations, intensive care unit admissions, and deaths. Psychiatry (Odds Ratio - $\mathrm{OR}=8.0$; 95\%CI 6-10.7; $\mathrm{p}<0.001)$, Palliative and Pain Care (OR=7.4; 95\%CI 5.7-9.7; $\mathrm{p}<0.001)$, Infectious Disease (OR=7.0; 95\%CI 6.4-7.8; $\mathrm{p}<0.001)$ and Nutrology $(\mathrm{OR}=6.9 ; 95 \% \mathrm{CI}$ 5.6-8.4; $\mathrm{p}<0.001)$ were the medical areas with higher chances of being one of the three or more medical specialties. Logistic regression analysis demonstrated that PCD patients followed by $\geq 3$ specialties were associated with higher risk of appointments/ patient $(>13)$ (OR=9.2; 95\%CI 8.0-10.5; $<<0.001)$, day hospital clinic visits $(\mathrm{OR}=4.8 ; 95 \% \mathrm{CI} 3.8-5.9 ; \mathrm{p}<0.001)$, emergency department visits (OR=3.2; 95\%CI 2.9-3.5; $\mathrm{p}<0.001)$, hospitalizations (OR=3.0; 95\%CI 2.7-3.3; $\mathrm{p}<0.001)$, intensive care admissions ( $\mathrm{OR}=2.5 ; 95 \% \mathrm{CI} 2.1-3.0 ; \mathrm{p}<0.001)$, and deaths $(\mathrm{OR}=2.8$; 95\%CI 1.9-4.0; $\mathrm{p}<0.001)$ (Table 2).

Of note, we evaluated 106,437 appointments of 16,237 children and adolescents with PCD. The diagnosis of each PCD patient was only considered once, thus resulting in a total of 37.057 diagnoses. More than 2,500 ICD-10 were registered in PCD patients. The 20 most prevalent ICD-10 observed in PCD patients were: asthma $(\mathrm{n}=1538 ; 4.15 \%)$, short stature $(\mathrm{n}=1054 ; 2.84 \%)$, leukemia $(\mathrm{n}=501 ; 1.35 \%)$, obesity $(\mathrm{n}=435 ; 1.17 \%)$, malformation syndromes $(\mathrm{n}=429 ; 1.16 \%)$, transplant $(\mathrm{n}=420 ; 1.13 \%)$, urinary tract infection $(\mathrm{n}=384$; $1.04 \%)$, epilepsy ( $n=306 ; 0.83 \%)$, hypothyroidism $(n=286$; $0.77 \%)$, pneumonia $(\mathrm{n}=282 ; 0.76 \%)$, chronic kidney disease $(\mathrm{n}=264 ; 0.71 \%)$, type 1 diabetes $(\mathrm{n}=248 ; 0.67 \%)$, chronic pain $(n=243 ; 0.66 \%)$, diarrhea $(n=244 ; 0.66 \%)$, malnutrition $(\mathrm{n}=214 ; 0.58 \%)$, constipation $(\mathrm{n}=214 ; 0.58 \%)$, juvenile idiopathic arthritis $(\mathrm{n}=186 ; 0.5 \%)$, high blood pressure $(\mathrm{n}=177$; $0.48 \%)$, cystic fibrosis $(\mathrm{n}=174 ; 0.47 \%)$, and primary immunodeficiency ( $\mathrm{n}=121 ; 0.33 \%)$.

Table 2 Characteristics of emergency department visits and hospitalization of 16,237 children and adolescents with pediatric chronic diseases followed in a University Hospital, according to the number of specialties/patient.

\begin{tabular}{|c|c|c|c|}
\hline & $\geq 3$ & $\leq 2$ & \multirow{2}{*}{ p-value } \\
\hline & $(n=2,016)$ & $(n=14,221)$ & \\
\hline Emergency department visits & 908 (45) & $2931(21)$ & $<0.001$ \\
\hline$\leq 2[n(\%)]$ & $502(25)$ & $2145(15)$ & $<0.001$ \\
\hline $3-6[n(\%)]$ & $281(14)$ & $655(5)$ & $<0.001$ \\
\hline$\geq 7[n(\%)]$ & $125(6)$ & $131(1)$ & $<0.001$ \\
\hline Hospitalizations [n (\%)] & $700(35)$ & $2,133(15)$ & $<0.001$ \\
\hline $1[n(\%)]$ & $268(13)$ & $1182(8)$ & $<0.001$ \\
\hline $2[n(\%)]$ & $1,244(6)$ & $446(3)$ & $<0.001$ \\
\hline$\geq 3[n(\%)]$ & $308(15)$ & $505(4)$ & $<0.001$ \\
\hline Intensive care unit admissions [n (\%)] & $173(9)$ & $511(4)$ & $<0.001$ \\
\hline $1[n(\%)]$ & $120(6)$ & $372(3)$ & $<0.001$ \\
\hline$\geq 2[n(\%)]$ & $53(3)$ & $139(1)$ & $<0.001$ \\
\hline Day hospital clinic visits [n (\%)] & $142(7)$ & $222(2)$ & $<0.001$ \\
\hline Deaths & $39(2)$ & $101(1)$ & $<0.001$ \\
\hline Age at death, years & $7.3 \pm 5.8$ & $7.6 \pm 5.6$ & 0.78 \\
\hline
\end{tabular}

Results are presented in $n$ (\%), median (range), or meantstandard deviation. 
Table 3 Multiple logistic regression analysis between the dependent variable ( $\geq 3$ specialties) and the number of appointments, type of medical specialty, hospitalizations, intensive care unit admissions, and deaths.

\section{\begin{tabular}{l|l|l} 
OR & $95 \% \mathrm{Cl}$ & p-value
\end{tabular}}

Number of appointments/patient

\begin{tabular}{|c|c|c|c|}
\hline $1-3$ & 0.02 & $0.18-0.3$ & $<0.001$ \\
\hline $4-12$ & 6.3 & $5.7-7.0$ & $<0.001$ \\
\hline$\geq 13$ & 9.2 & $8.0-10.5$ & $<0.001$ \\
\hline \multicolumn{4}{|l|}{ Type of medical specialty } \\
\hline Cardiology & 5.3 & $4.5-6.1$ & $<0.001$ \\
\hline Endocrinology & 2.8 & $2.6-3.1$ & $<0.001$ \\
\hline Gastroenterology & 5,9 & $5.2-6.8$ & $<0.001$ \\
\hline Genetics & 4.2 & $3.7-4.7$ & $<0.001$ \\
\hline Hematology & 2.8 & $2.4-3.4$ & $<0.001$ \\
\hline $\begin{array}{l}\text { Hematopoietic cell } \\
\text { Transplantation }\end{array}$ & 5.2 & $3.7-7.3$ & $<0.001$ \\
\hline Hepatology & 4.5 & $4.0-5.1$ & $<0.001$ \\
\hline Immunology and allergy & 2.7 & $2.3-3.1$ & $<0.001$ \\
\hline Infectious disease & 7.0 & $6.4-7.8$ & $<0.001$ \\
\hline $\begin{array}{l}\text { Nephrology and renal } \\
\text { Transplantation }\end{array}$ & 4.5 & $4.0-5.0$ & $<0.001$ \\
\hline Neurology & 3.6 & $3.1-4.1$ & $<0.001$ \\
\hline Nutrology & 6.9 & $5.6-8.4$ & $<0.001$ \\
\hline Oncology & 1.0 & $0.9-1.2$ & 0.92 \\
\hline Orthopedics & - & - & - \\
\hline Palliative and pain care & 7.4 & $5.7-9.7$ & $<0.001$ \\
\hline $\begin{array}{l}\text { Pediatric surgery and } \\
\text { liver transplantation }\end{array}$ & 2.3 & $2.1-2.7$ & $<0.001$ \\
\hline Pulmonology & 4.4 & $3.9-5.0$ & $<0.001$ \\
\hline Psychiatry & 8.0 & $6.0-10.7$ & $<0.001$ \\
\hline Rheumatology & 2.4 & $2.0-2.9$ & $<0.001$ \\
\hline Others & - & - & - \\
\hline Day hospital clinic visits & 4.8 & $3.8-5.9$ & $<0.001$ \\
\hline Emergency department visits & 3.2 & $2.9-3.5$ & $<0.001$ \\
\hline$\leq 2$ & 1.9 & $1.7-2.1$ & $<0.001$ \\
\hline $3-6$ & 3.4 & $2.9-3.9$ & $<0.001$ \\
\hline$\geq 7$ & 7.1 & $5.5-9.2$ & $<0.001$ \\
\hline Hospitalizations & 3.0 & $2.7-3.3$ & $<0.001$ \\
\hline 1 & 1.7 & $1.5-1.9$ & $<0.001$ \\
\hline 2 & 2.0 & $1.6-2.5$ & $<0.001$ \\
\hline$\geq 3$ & 4.9 & $4.2-5.7$ & $<0.001$ \\
\hline $\begin{array}{l}\text { Intensive care unit } \\
\text { admissions }\end{array}$ & 2.5 & $2.1-3.0$ & $<0.001$ \\
\hline 1 & 2.4 & $1.9-2.9$ & $<0.001$ \\
\hline$\geq 2$ & 2.7 & $2.0-3.8$ & $<0.001$ \\
\hline Deaths & 2.8 & $1.9-4.0$ & $<0.001$ \\
\hline
\end{tabular}

OR: Odds Ratio; $95 \% \mathrm{Cl}$ : confidence interval of $95 \%$.
Table 3 presents further comparisons of the 20 most prevalent associated diagnoses based on 37,057 ICD-10 descriptions, according to the number of specialties/patient. The diagnosis of asthma, obesity, chronic pain, transplant, urinary tract infection, pneumonia, chronic kidney disease, malnutrition, epilepsy, hypothyroidism, high blood pressure, diarrhea, constipation, and immunodeficiency were significantly higher in patients followed by $\geq 3$ specialties compared to those followed by $\leq 2$ specialties (Table 4 ).

Table 4 Comparison of the 20 most prevalent diagnosis based on 37,057 International Statistical Classification of Diseases and Related Health Problems descriptions, according to the number of specialties/patient.

\begin{tabular}{|c|c|c|c|}
\hline & \multicolumn{2}{|c|}{$\begin{array}{c}\text { Number of specialties/ } \\
\text { patient }\end{array}$} & \multirow{2}{*}{ p-value } \\
\hline & $\begin{array}{c}\geq 3(n=8,136) \\
n(\%)\end{array}$ & $\begin{array}{c}\leq 2(\mathrm{n}=28,921) \\
\mathrm{n}(\%)\end{array}$ & \\
\hline Asthma & $383(4.7)$ & $1,155(4.0)$ & 0.005 \\
\hline Short stature & 205 (2.5) & 849 (2.9) & 0.05 \\
\hline Obesity & $134(1.6)$ & $301(1.0)$ & $<0.001$ \\
\hline Chronic pain & $123(1.5)$ & $120(0.4)$ & $<0.001$ \\
\hline Transplant & $116(1.4)$ & $304(1.1)$ & 0.006 \\
\hline $\begin{array}{l}\text { Urinary tract } \\
\text { infection }\end{array}$ & $115(1.4)$ & $269(0.9)$ & $<0.001$ \\
\hline Pneumonia & $110(1.4)$ & $172(0.6)$ & $<0.001$ \\
\hline $\begin{array}{l}\text { Chronic kidney } \\
\text { disease }\end{array}$ & $106(1.3)$ & $158(0.5)$ & $<0.001$ \\
\hline Malnutrition & $105(1.3)$ & $109(0.4)$ & $<0.001$ \\
\hline Epilepsy & $92(1.1)$ & $214(0.7)$ & 0.001 \\
\hline Hypothyroidism & $88(1.1)$ & $198(0.7)$ & $<0.001$ \\
\hline $\begin{array}{l}\text { High blood } \\
\text { pressure }\end{array}$ & $83(1.0)$ & $94(0.3)$ & $<0.001$ \\
\hline Diarrhea & $80(1.0)$ & $164(0.6)$ & $<0.001$ \\
\hline $\begin{array}{l}\text { Malformation } \\
\text { syndromes }\end{array}$ & $80(1.0)$ & $349(1.2)$ & 0.10 \\
\hline Constipation & $73(0.9)$ & $141(0.5)$ & $<0.001$ \\
\hline $\begin{array}{l}\text { Primary } \\
\text { immunodeficiency }\end{array}$ & $48(0.6)$ & $73(0.3)$ & $<0.001$ \\
\hline Leukemia & $44(0.5)$ & $457(1.6)$ & $<0.001$ \\
\hline Type 1 diabetes & $41(0.5)$ & $207(0.7)$ & 0.04 \\
\hline Cystic fibrosis & $39(0.5)$ & $135(0.5)$ & 0.86 \\
\hline $\begin{array}{l}\text { Juvenile } \\
\text { idiopathic } \\
\text { arthritis }\end{array}$ & $36(0.4)$ & $150(0.5)$ & 0.42 \\
\hline
\end{tabular}

Results are presented in $n$ (\%). 


\section{DISCUSSION}

The present study showed that PCD patients who required simultaneous care from multiple medical specialties had complex and severe diseases, with specific diagnoses.

The prevalence of PCDs has increased in the last half-century. Chronic diseases in pediatric populations that interfere with daily activities have increased more than $400 \%$ after 1960 , resulting in greater medical complexity in clinical practice. ${ }^{22}$ Our study demonstrated that PCD patients followed by various medical specialties had high morbidity and mortality rates, with emergency department visits, hospitalizations, intensive care admissions, and deaths. These PCD patients needed frequent appointments at outpatient clinics, a fact that could lead to higher financial costs, requiring specific policies and interventions. ${ }^{1,22}$

Moreover, PCD patients of the present study followed by various medical specialties showed heterogeneity of diagnosis and subspecialties. Infectious Disease was the most frequent specialty for these patients, probably due to recurrent and severe infections, requiring multiple hospitalizations in immunosuppressed patients. ${ }^{15-18}$ Despite the relevant hospital-acquired infection committee, vaccination programs, and specific antibiotic and antifungal treatments for different PCDs in our University Hospital, patients might have many contributing factors for infections. These factors may be related to the disease itself (disease duration, lymphopenia, leukopenia, neutropenia, disease activity, functional asplenia, and primary immunodeficiencies) and its treatment (glucocorticoid and immunosuppressant agents). ${ }^{13,15,16,18,23,24}$

Endocrinology, Nephrology, Renal Transplantation, Pediatric Surgery, and Liver Transplantation were also frequent subspecialties in patients followed by more than three concomitant specialties. This fact results from a specific situation of our tertiary hospital, which is a reference center for the most common and severe endocrine, kidney, liver, and congenital diseases in Brazil. ${ }^{14,16,25}$

Importantly, Psychiatry and Palliative and Pain Care were the medical areas in which the patient had a great chance of being followed by three or more medical specialties. This finding is related to the medical complexities in our critically ill patients, ${ }^{25,26}$ who may also present several mental health conditions and chronic pain diseases.

Asthma was the main diagnosis associated with PCD patients followed by $\geq 3$ specialties. The prevalence of this relevant diagnosis in the city of Sáo Paulo ranges from 4.9 to $10.2 \%$, similarly to our data. ${ }^{27}$ Additionally, $22 \%$ of adolescents reported wheezing symptoms. ${ }^{28}$ This chronic disease might lead to more frequent admission rates, requiring emergency department visits, hospitalizations, and intensive care admissions. Therapeutic optimization for PCD patients should be an important goal to attain. ${ }^{13,27}$

Short stature was also relevant herein, a multifactorial finding related to long disease duration, chronic inflammatory diseases, physical inactivity, and therapies (such as glucocorticoid). In addition, Endocrinology and Nutrology were significant specialties due to the increase in obesity in the general population, as well as in chronic disease patients. ${ }^{29}$

Pediatric care systems and multidisciplinary health teams should develop evidence-based solutions to the challenges of caring for and treating PCD patients with a medically complex disease. ${ }^{23}$ Strategies should be devised focusing on reducing hospital admission rates, thus improving hospital care for these patients.

The strong point of this study was the large population with different PCDs defined by ICD-10 descriptions and followed in a tertiary and pediatric teaching hospital. Our university hospital is a Brazilian reference center for pediatric and complex specialties that follows PCDs. This center is well known for its high standard and humane care, has many health care providers, modern resources with clinical/laboratory research and drug trials, evaluating children and adolescents with medically complex conditions. ${ }^{1,15,16}$ The main limitations of the present study were the short evaluating period and its cross-sectional design.

In conclusion, the present study showed that PCD patients who needed care from multiple medical specialties had complex and severe diseases. PCD patients presented specific diagnoses, particularly asthma, short stature, and leukemia.

\section{ACKNOWLEDGMENTS}

We thank Thiago de Freitas Passone for the database and all physicians of pediatric specialties, multidisciplinary groups, and Informatics team of our university hospital.

\section{Funding}

This study was funded by grants from the Conselho Nacional de Desenvolvimento Científico e Tecnológico (CNPq; 303422/2015-7 to CAS), Fundação de Amparo à Pesquisa do Estado de São Paulo (FAPESP; 2015/03756-4 to CAS), Federico Foundation, Switzerland (to CAS) and by the Núcleo de Apoio à Pesquisa "Saúde da Criança e do Adolescente" (NAP-CriAd) from Universidade de Sáo Paulo (to MCS and CAS).

\section{Conflict of interests}

The authors declare no conflict of interests. 


\section{REFERENCES}

1. Alveno RA, Miranda CV, Passone CG, Waetge AR, Hojo ES, Farhat SC, et al. Pediatric chronic patients at outpatient clinics: a study in a Latin American University Hospital. J Pediatr (Rio J). 2018;94:539-45. http://dx.doi.org/10.1016/j. jped.2017.07.014

2. Hernandez C, Jansa M, Vidal M, Nuñez M, Bertran MJ, Garcia-Aymerich J, et al. The burden of chronic disorders on hospital admissions prompts the need for new modalities of care: a cross-sectional analysis in a tertiary hospital. QJM. 2009;102:193-202. https://doi.org/10.1093/qjmed/hcn172

3. Araújo P, Carvalho MG, Weelden M, Lourenço B, Queiroz LB, Silva CA. Substance misuse and sexual function in adolescents with chronic diseases. Rev Paul Pediatr. 2016;34:323-9. http://dx.doi.org/10.1016/j.rppede.2015.10.008

4. Escobar AM, Grisi SJ. 21st century well-child care. Rev Assoc Med Bras. 2016;62:479-81. http://dx.doi.org/10.1590/18069282.62.06.479

5. Sargsyan S, Movsesyan Y, Melkumova M, Babloyan A. child and adolescent health in Armenia: experiences and learned lessons. J Pediatr. 2016;177S:S21-34. https://doi. org/10.1016/j.jpeds.2016.04.038

6. Mokkink LB, van der Lee $\mathrm{JH}$, Grootenhuis MA, Offringa M, Heymans HS, Dutch National Consensus Committee Chronic Diseases and Health Conditions in Childhood. Defining chronic diseases and health conditions in childhood (0-18 years of age): national consensus in the Netherlands. Eur $\mathrm{J}$ Pediatr. 2008;167:1441-7. https://doi.org/10.1007/s00431008-0697-y

7. Babloyan A, Sargsyan S, Melkumova M, Movsesyan Y. Health behavior in school-aged children. Yerevan, Armenia: Arabkir Medical Center, Institute of child and adolescent health and UNICEF; 2012.

8. Choe SA, Cho SI. Causes of child mortality (1 to 4 years of age) from 1983 to 2012 in the Republic of Korea: national vital data. J Prev Med Public Health. 2014;47:336-42. https:// doi.org/10.3961/jpmph.14.024

9. Yu JW, Adams SH, Burns J, Brindis CD, Irwin CE Jr. Use of mental health counseling as adolescents become young adults. J Adolesc Health. 2008;43:268-76. https://doi. org/10.1016/j.jadohealth.2008.01.009

10. Batra S, Ng EY, Foo F, Noori O, McCaskill M, Steinbeck K. Older adolescent presentations to a children's hospital emergency department. Emerg Med Australas. 2016;28:419-24. https://doi.org/10.1111/17426723.12608

11. Crow SS, Undavalli C, Warner DO, Katusic SK, Kandel P, Murphy SL, et al. Epidemiology of pediatric critical illness in a population-based birth cohort in Olmsted County, MN. Pediatr Crit Care Med. 2017;18:e137-45. https://doi. org/10.1097/PCC.0000000000001084

12. Rachas A, Tuppin P, Meyer L, Falissard B, Faye A, Mahlaoui N, et al. Excess mortality and hospitalizations in transitional-age youths with a long-term disease: a national population-based cohort study. PLoS One. 2018;13:e0193729. https://doi. org/10.1371/journal.pone.0193729
13. Solé D, Camelo-Nunes IC, Wandalsen GF, Mallozi MC. Asthma in children and adolescents in Brazil: contribution of the International Study of Asthma and Allergies in Childhood (ISAAC). Rev Paul Pediatr. 2014;32:114-25. https://doi. org/10.1590/S0103-05822014000100018

14. Della Manna T, Setian N, Savoldelli RD, Guedes DR, Kuperman $\mathrm{H}$, Menezes HC Filho, et al. Diabetes mellitus in childhood: an emerging condition in the 21st century. Rev Assoc Med Bras (1992). 2016;62:594-601. https://doi.org/10.1590/18069282.62.06.594

15. Carneiro-Sampaio M, Moraes-Vasconcelos D, Kokron CM, Jacob CM, Toledo-Barros M, Dorna MB, et al. Primary immunodeficiency diseases in different age groups: a report on 1,008 cases from a single Brazilian reference center. J Clin Immunol. 2013;33:716-24. https://doi.org/10.1007/ s10875-013-9865-6

16. Gormezano NW, Otsuzi Cl, Barros DL, Silva MA, Pereira RM, Campos LM, et al. Macrophage activation syndrome: a severe and frequent manifestation of acute pancreatitis in 362 childhood-onset compared to 1830 adult-onset systemic lupus erythematosus patients. Semin Arthritis Rheum. 2016;45:706-10. https://doi.org/10.1016/j. semarthrit.2015.10.015

17. Tannuri AC, Lima F, Mello ES, Tanigawa RY, Tannuri U. Prognostic factors for the evolution and reversibility of chronic rejection in pediatric liver transplantation. Clinics (Sao Paulo). 2016;71:216-20. https://doi.org/10.6061/ clinics/2016(04)07

18. Brunelli JB, Schmidt AR, Sallum AM, Goldenstein-Schainberg C, Bonfá E, Silva CA, et al. High rate of serious infection in juvenile idiopathic arthritis patients under biologic therapy in a real-life setting. Mod Rheumatol. 2018;28:264-70. https://doi.org/10.1080/14397595.2017.1349059

19. Bermudes AC, Carvalho WB, Zamberlan P, Muramoto $G$, Maranhão RC, Delgado AF. Changes in lipid metabolism in pediatric patients with severe sepsis and septic shock. Nutrition. 2018;47:104-9. https://doi.org/10.1016/j. nut.2017.09.015

20. Duarte RJ, Cristofani LM, Odone Filho V, Srougi M, Dénes FT. Videolaparoscopic radical nephrectomy after chemotherapy in the treatment of Wilms' tumor: Long-term results of a pioneer group. J Pediatr Urol. 2017;13:50.e1-50.e5. https:// doi.org/10.1016/j.jpurol.2016.09.004

21. World Health Organization. International statistical classification of diseases and related health problems [Internet]. Geneva: WHO; 2011 [cited on February 2018] Available from: http://www.who.int/classifications/icd/ ICD10Volume2_en_2010.pdf.

22. Cohen E, Berry JG, Sanders L, Schor EL, Wise PH. Status Complexicus? The emergence of pediatric complex care. Pediatrics. 2018;141 Suppl 3:S202-11. https://doi. org/10.1542/peds.2017-1284E

23. Litvinov N, Silva MT, van der Heijden IM, Graça MG, Marques de Oliveira L, Fu L, et al. An outbreak of invasive fusariosis in a children's cancer hospital. Clin Microbiol Infect. 2015;21:268. e1-7. https://doi.org/10.1016/j.cmi.2014.09.004 
24. Silva CA, Aikawa NE, Pereira RM, Campos LM. Management considerations for childhood-onset systemic lupus erythematosus patients and implications on therapy. Expert Rev Clin Immunol. 2016;12:301-13. https://doi.org/10.158 6/1744666X.2016.1123621

25. Tannuri AC, Porta G, Miura IK, Santos MM, Moreira DA, Rezende NM, et al. Pediatric acute liver failure in Brazil: Is living donor liver transplantation the best choice for treatment? Liver Transpl. 2016;22:1006-13. https://doi. org/10.1002/tt.24435

26. Nelson KE, Feinstein JA, Gerhardt CA, Rosenberg AR, Widger $\mathrm{K}$, Faerber $\mathrm{JA}$, et al. Emerging methodologies in pediatric palliative care research: six case studies. Children (Basel). 2018;5.pii:E32. https://doi.org/10.3390/children5030032
27. Solé $D$, Yamada E, Vana AT, Werneck G, Solano de Freitas $L$, Sologuren MJ, et al. International Study of Asthma and Allergies in Childhood (ISAAC): prevalence of asthma and asthma-related symptoms among Brazilian schoolchildren. J Investig Allergol Clin Immunol. 2001;11:123-8.

28. Pastorino AC, Rimazza RD, Leone C, Castro AP, Solé D, Jacob CM. Risk factors for asthma in adolescents in a large urban region of Brazil. J Asthma. 2006;43:695-700. https://doi. org/10.1080/02770900600925544

29. Belle FN, Weiss A, Schindler M, Goutaki M, Bochud $M$, Zimmermann $\mathrm{K}$, et al. Overweight in childhood cancer survivors: the Swiss childhood cancer survivor study. Am J Clin Nutr. 2018;107:3-11. https://doi.org/10.1093/ ajcn/nqx006 